\title{
A Role of Extracellular Polysaccharides of Xanthomonas campestris pv. citri in Bacterial Adhesion to Citrus Leaf Tissues in Preinfectious Stage
}

\author{
Toshinobu TAKaHaSh** and Noriyuki DoKE* \\ 高橋敏房*・道家紀志* : カンキツかいよう病菌の感染前過程に \\ おけるカンキツ葉組織への付着と菌体外多糖質の役割
}

\begin{abstract}
Unwashed bacterial cells of Xanthomonas campestris pv. citri were found to adhere preferentially to a wounded portion of citrus leaf tissues rather than intact leaf surfaces. Washed bacterial cells of $X$. campestris pv. citri and unwahsed bacterial cells of a colony mutant lacking the ability to produce extracellular polysaccharides (EPS) hardly adhered even to wounded tissues of citrus leaves.

The adhesion of unwashed bacterial cells was inhibited when the wounded leaf tissues were pretreated either with $\mathrm{D}$-glucosamine, pronase or low $\mathrm{pH}$ citrate buffer. The adhesion of unwashed bacterial cells was also observed to the disks of various nonhost tissues to an extent, but it was not influenced by the pretreatment with D-glucosamine solution at all.

These results suggested that $X$. campestris pv. citri adhered to host tissues through the EPS-agglutinin interaction and that the process might involved in the initial step for establishing the host-parasite relationship in citrus canker.
\end{abstract}

(Received October 17, 1983)

Key Words : citrus canker, extracellular polysaccharides, citrus leaves, Xanthomonas campestris pv. citri.

\section{Introduction}

It is well known that phytopathogenic bacteria invade their host plants through natural openings such as stomata and hydathodes or via wounds. In some cases, wounds make a causal bacteria to infect easier a host plant than natural openings. Goto ${ }^{9)}$ has repor'ed that the minimal dose of Xanthomonas campestris pv. citri necessary for infection through stomata and wounded tissues was about $10^{5}$ cells $/ \mathrm{ml}$ and $10^{2}$ to $10^{3}$ cells $/$ $\mathrm{m} 1$, respectively. In cases of citrus canker and rice bacterial blight, wounds caused by wind or insects are reported to be the infection sites to cause a severe symptom of these diseases ${ }^{8,9,18,27)}$.

We have many papers reporting a role of host lectins in the bacterial adhesion or entrapment to host cell walls of compatible or incompatible interactions ${ }^{1-5,10-17,19,26)}$. In some incompatible systems, attachment of bacterial cells to host cell walls induces a hypersensitive reaction by host tissues ${ }^{11-17,19,20)}$. On the other hand, adhesion of bacterial cells to host cell walls in rhizobium-host systems is interpreted as a process in-

* Faculty of Agriculture, Nagoya University, Nagoya 464, Japan 名古屋大学農学部

Present address of senior author Ube Research Laboratory, Fine Chemicals Development Department, Ube, Yamaguchi 755, Japan 現在: 宇部興産中央研究所 
dispensable for the establishment of a compatible interaction ${ }^{1-3,6,10,26)}$.

We ${ }^{21,23,24)}$ have found that citrus leaves contain a glycoprotein which reacts to agglutinate with the extracellular polysaccharides (EPS) of X. campestris pv. citri in vitro, at $\mathrm{pH}$ lower than $6.0^{21,23,24)}$. The activity of agglutinin was found to be specifically inhibited by $\mathrm{D}$-glucosamine and the agglutinin was released from host cell tissues at $\mathrm{pH}$ $4.0^{21,23,24)}$.

In this report, we describe a possible role of the citrus leaf agglutinin which plays in the specific adhesion of bacterial cells of $X$. campestris pv. citri to wounded citrus leaf tissues through EPS. A brief report of this study has already been published elsewhere ${ }^{22)}$.

\section{Materials and Methods}

Bacteria and culture. Virulent strains of Xanthomonas campestris pv. citri (U9-1) and $X$. campestris pv. campestris (NA-1), nonpathogenic to citrus plants, were kindly furnished by the collections of Plant Pathology Laboratory, Faculty of Agriculture, Shizuoka University. A mutant strain of $X$. campestris pv. citri (U9-1 CM), which had lost the EPS producing ability, was isolated from slimeless colonies generated spontaneously during cultures of the vilulent strain (U9-1) on a potato-sucrose agar (PSA) medium. Each culture was maintained at $28 \mathrm{C}$ by at least weekly transfer to the fresh PSA slant.

The vilulent strain (U9-1) grown on the PSA slant for 2 days at $28 \mathrm{C}$ was used for experiments. The cells harvested from the typical colonies were gently suspended in sterile distilled water. These cells are henceforth referred to as the unwashed bacteria. To remove EPS from the cells, the suspension of the unwashed bacterial cells was vigorously stirred with a Bortex mixer for $30 \mathrm{sec}$ at the maximum vibration, then was centrifuged for $30 \mathrm{~min}$ at $20,000 \times \mathrm{g}$. Precipitated cells were suspended again in sterile distilled water and washed twice more by the above method. These cells, obtained by centrifugation and having virtually no EPS around them, are henceforth reffered to as the washed bacteria. The cell concentration of washed and unwashed facteria was adjusted to about $1 \times 10^{8}$ cells $/ \mathrm{ml}$ by dilution using a standard curve showing the relationship between the optical density of bacterial suspension at $540 \mathrm{~nm}$ ani colony forming unit (CFU).

Plant materials. As host plants, Natsudaidai (Citrus natsudaidai Hayata (Rutac.), Caramondin (C. madurnsis Lour (Rutac.)), Satsuma (C. unshiu Mars. (Rutac.)), Hassaku (C. hassaku Tanaka), Iyo-kan (C. iyo Tanaka) and Ponkan (C. reticulata Blanco (Rutac.)) were used. As nonhost plants, tobacco (Nicotiana tabacum L. vr. Samsun), tomato (Lycopersicon escurentum Mill, vr. Fukuju), Strawberry (Fragaria grandiflora Ehr. vr. Hokowase), French bean (Phaseolus vulgaris L. vr. Kairyo-otebo) and cabbage (Brassica oleracea L. vr. capitata) were used. All plants were grown in a green house, and their fully expanded leaves were used in the experiments.

The following leaf materials were prepared for the adhesion experiments of bacterial cell to plant tissues: (1) intact whole leaves, (2) whole leaves of which the upper sur- 
face was rubbed with carborundum (600 mesh), (3) leaf disks, $10 \mathrm{~mm}$ in diameter, cut out from intact whole leaves, (4) leaf disks, $10 \mathrm{~mm}$ in diameter, cut out from whole leaves rubbed with carborundum, (5) leaf tissue pieces having a definite surface area $\left(0.64 \mathrm{~cm}^{2}\right)$ and different lengths of cut edges (32, 48, 64 and $\left.80 \mathrm{~mm}\right)$, (6) leaf disks, 10 $\mathrm{mm}$ in diameter, pretreated for $2 \mathrm{hr}$ at $37 \mathrm{C}$ in a pronase solution $(500 \mu \mathrm{g} / \mathrm{ml}$ of pronase

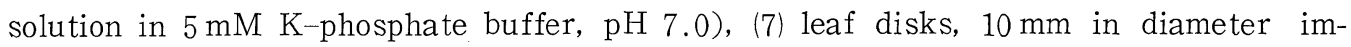
mersed in D-glucosamine solution $(9 \mathrm{mg} / \mathrm{ml})$ for $10 \mathrm{~min}$, (8) leaf disks, $10 \mathrm{~mm}$ in diameter, pretreated with EPS of $X$. campestris pv. citri or $X$. campestris pv. campestris for $10 \mathrm{~min}$, and (9) leaf disks, $10 \mathrm{~mm}$ in diameter, immersed in $50 \mathrm{mM}$ citrate buffer, $\mathrm{pH} 4.0$ for $2 \mathrm{hr}$.

Preparation of extracellular polysaccharides. The supernatant obtained by centrifugation of washed bacterial suspension as mentioned above was filtered through a membrane filter (Amicon, pore size; $0.22 \mu$ ). Three volumes of ethanol were added to the filtrate in order to obtain precipitation of crude EPS. The precipitate collected by centrifugation at $10,000 \times g$ was dissolved in distilled water, and treated with phenolwater according to the method of Sequeira and Graham ${ }^{16)}$. Components soluble in water were used as extracellular polysaccharides (EPS) after dialysis against distilled water. The EPS concentration was determined by the method described in the previous report ${ }^{24)}$.

Assay of bacterial cell adhesion to tissues. The leaf tissue preparations mentioned above were immersed in a suspension of bacterial cells $\left(1 \times 10^{8}\right.$ cells $\left./ \mathrm{ml}\right)$ for 10 min at room temperature, and were stirred gently in stelile distilled water $(10 \mathrm{ml}) 10$ times. The leaf tissues were then homogenized with sterile distilled water in a glass homogenizer ( $1 \mathrm{ml} /$ disks). An aliquot $(50 \mu 1)$ of diluted homogenate was spread over on the PSA plates and the number of the colony formed after 2 day-incubation was counted. The bacterial suspension was mixed with the leaf homogenate before plating to confirm that the bacterial colony formation was free from the effect of leaf tissue preparation.

\section{Results}

\section{Adhesion of unwashed bacterial cells}

Intact citrus leaves without wound and those rubbed with carborundum were immersed in the cell suspension of $X$. campestris pv. citri, and then the number of bacterial cells adhering to a definite area of leaf surface was determined (Table 1). The number of the unwashed bacterial cells adhered to the unwounded leaf tissues was recorded to be $2 \times 10^{3}$ cells/disk ( $1 \mathrm{~cm}$ in diameter, $0.79 \mathrm{~cm}^{2}$ in area). This means that about 2,500 bacterial cells was adhered to $1 \mathrm{~cm}^{2}$ of leaf surface. Adhesion of unwashed bacterial cells to the wounded leaf rubbed with carborundum was about 10 times as much as those on the unwounded leaves (Table 1).

The adhered bacterial cells to intact leaf disks prepared before immersion in the bacterial suspension was about 5 times heavier than to those prepared after immersion. The adhered cells was found to be about 70 times heavier to disks prepared from leaves 
Table 1. Adhesion of unwashed bacterial cells of Xanthomonas campestris pv. citri to intact and wounded tissues of citrus leaves, Citrus natsudaidai.

\begin{tabular}{|c|c|}
\hline Tissues exposed to bacteria & $\begin{array}{l}\text { Number of adherent bacteria } \\
(\text { (cells/disk) a) }\end{array}$ \\
\hline Whole leaf ${ }^{\text {b) }}$ & $2.0 \times 10^{3}$ \\
\hline Whole leaf rubbed with carborundum ${ }^{\text {c) }}$ & $2.0 \times 10^{4} \pm 1.2 \times 10^{4}$ \\
\hline Leaf disk $^{\mathbf{d})}$ & $1.0 \times 10^{5} \pm 2.0 \times 10^{4}$ \\
\hline Leaf disk rubbed with carborundume) & $1.4 \times 10^{5} \pm 3.2 \times 10^{4}$ \\
\hline
\end{tabular}

a) Leaf disks were homogenized with water $(1 \mathrm{ml} /$ disk). An aliquot of homogenate was subjected to colony assay.

b) and c) Leaf disks, $1 \mathrm{~cm}$ in diameter, were prepared after whole leaf was exposed to a bacterial suspension $\left(1 \times 10^{8} \mathrm{cells} / \mathrm{ml}\right)$ and washed.

d) and e) Leaf disks prepared from whole leaf were exposed to the bacterial suspension.

rubbed with carborundum than to those prepared from intact leaves (Table 1). These experiments demonstrated that the unwashed bacterial cells of $X$. campestris pv. citri adhered preferentially to wounded portions of citrus leaf tissues rather than intact leaf surfaces. The number of bacterial cells meant the living bacteria firmly adhering to host tissues, because all leaf samples were washed 10 times with distilled water after immersion in the bacterial suspension until few bacterial cells were liberated.

Fig. 1 shows the results of a quantitative analysis of the unwashed bacterial cell adhered to leaf pieces having the same surface area and different lengths of cut edges. The number of bacterial cells that adhered to the leaf pieces was clearly proportional to the length of wounded edge of citrus leaves. It indicated that the unwashed bacterial cells adhered dominantly to wounded edges of leaf tissues.

\section{Adhesion of washed bacterial cells and EPS-nonproducing mutant cells}

Citrus leaf disks were immersed in a suspension of the washed bacterial cells of $X$. campestris pv. citri. The washed bacterial cells bearing virtually no EPS around cell recorded $33.3 \%$ of the adhesion observed for the unwashed bacterial cells (Table 2). On the other hand, the unwashed bacterial cells of a colony mutant of $X$. campestris pv. citri, which lacked the EPS-forming ability, recorded $26.7 \%$ of the adhesion noted for the unwashed parental bacterial cells having the EPS-forming ability (Table 2). This value was almost the same as that of the washed bacterial cells.

The unwashed cells of $X$. campestris pv. campestris, a xanthomonad nonpathogenic to citrus plants, was $32.0 \%$ of the unwashed bacterial cells of $X$. campestris pv. citri (Table 2).

\section{Bacterial adhesion and its inhibition}

Citrus leaf disks were exposed to the unwashed bacterial cells after they were treated with EPS isolated from $X$. campestris pv. citri. The number of bacterial cells adhering to those EPS-treated leaf disks was far smaller than the ones to the nontreated disks. The EPS treatment, however, showed no influence on the washed bacterial cell adhesion to the disks (Table 2). The pretreatment with EPS isolated from X. campestris pv. campestris had any influence on the adhesion to both unwashed and washed bacterial cells of $X$. campestris pv. citri. 


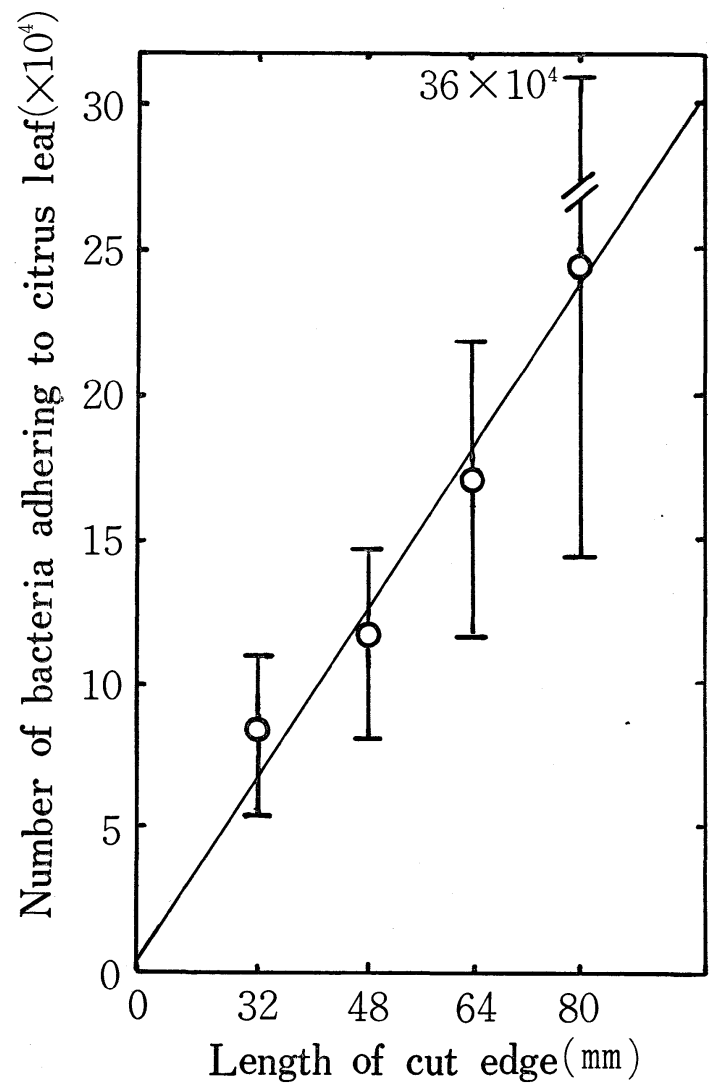

Fig. 1. Correlation between number of bacterial cells of Xanthomonas campestris pv. citri adherining to citrus leaf pieces and length of cut edge of the leaf pieces. The leaf pieces with same surface area $\left(0.64 \mathrm{~cm}^{2}\right)$ and different lengths of cut edge were prepared from whole leaves (Citrus natsudaidai). Each leaf piece was immersed in a suspension of unwashed bacterial cells $\left(1 \times 10^{8} \mathrm{cells} / \mathrm{ml}\right)$ for $10 \mathrm{~min}$, and then washed. Number of the bacterial cell adhering to them was assayed by counting number of colonies which appeared 2 days after plating of an aliquot of the leaf homogenate on PSA medium. Each value represents the average of three experiments with S.D.

It is known that citrus leaf tissues contain an agglutinin, a kind of glycoprotein which forms a complex with EPS of $X$. campestris pv. citri, and that agglutination was liberated from wounded tissues at $\mathrm{pH} 4.0^{21,23,24)}$. Its activity was also found to be inhibited by $\mathrm{D}$-glucosamine ${ }^{21-24)}$. When the citrus leaf disks pretreated with pronase were exposed to the unwashed bacterial cells, the number of adherent bacterial cells was far smaller than the ones in the case of untreated leaf disks (Table 2). The leaf disks pretreated with D-glucosamine also greatly reduced the number of unwashed bacterial cells adhering to the disks, but not to the washed bacterial cells (Table 2). The leaf disks pretreated with the citrate buffer at $\mathrm{pH} 4.0$ was adhered by a far smaller number of unwashed bacterial cells than those pretreated with distilled water (Table 2). 
Table 2. Adhesion of bacterial cells of Xanthomonas campestris pv. citri and X. campestris pv. campestris to citrus leaf disks pretreated with extracellular polysaccharides (EPS) of the bacteria, pronase, D-glucosamine or low $\mathrm{pH}$ solution.

\begin{tabular}{|c|c|c|c|}
\hline Bacteria $\left.^{a}\right)$ & & Pretreatment ${ }^{\mathrm{b})}$ & $\begin{array}{l}\text { Relative value of adherent } \\
\text { bacteria }(\%)\end{array}$ \\
\hline Xanthomonas campestris pv. citri & Unwashed cells & Water & $100^{c)}$ \\
\hline " & Unwashed cells & EPS & 72.0 \\
\hline " & Unwashed cells & Pronase & 33.3 \\
\hline " & Unwashed cells & D-glucosamine & 37.3 \\
\hline " & Unwashed cells & $\mathrm{pH} 4.0$ & 17.3 \\
\hline " & Washed cells & Water & 33.3 \\
\hline " & Washed cells & EPS & 32.0 \\
\hline $\begin{array}{r}X . \text { campestris pv. citri } \\
\text { (colony mutant) }\end{array}$ & Unwashed cells & Water & 26.7 \\
\hline X. campestris pv. campestris & Unwashed cells & Water & 32.0 \\
\hline
\end{tabular}

a) $1 \times 10^{8} \mathrm{cells} / \mathrm{ml}$

b) Leaf disks, $10 \mathrm{~mm}$ in diameter, were immersed in a solution containing EPS of $X$. campestris pv. citri $(-1 \mathrm{mg} / \mathrm{ml})$ for $10 \mathrm{~min}$, pronase $(500 \mu \mathrm{g} / \mathrm{ml})$ for $2 \mathrm{hr}$ at $37 \mathrm{C}, \mathrm{D}$ glucosamine $(9 \mathrm{mg} / \mathrm{ml})$ for $10 \mathrm{~min}$ or in citrate buffer $(50 \mathrm{mM}$. pH 4.0).

c) Number of adherent bacteria: $1.4 \times 10^{5}$ cells/disk

Table 3. Adhesion of unwashed bacterial cells of Xanthomonas campestris pv. citri to leaf disks of host and nonhost plants, and effect of D-glucosamine on the adhesion

\begin{tabular}{l|c|c}
\hline \hline Leaf disks of Plants & Relative value of adhered bacteria (\%) $)$ & $\begin{array}{l}\text { Inhibition by }{ }^{\mathrm{b})} \\
\text { D-glucosamine }(\%)\end{array}$ \\
\hline Host plants & 100 & 63 \\
Natsudaidai & 137 & 62 \\
Caramondin & 145 & 67 \\
Satsuma & 100 & 30 \\
Hassaku & 94 & 37 \\
Iyo-kan & 81 & 36 \\
Ponkan & & 0 \\
Nonhost plants & 72 & 0 \\
Tobacco vr. Samsun & 86 & 0 \\
Tomato vr. Fukuju & 62 & 0 \\
Strawberry vr. Hoko-wase & 35 & 0 \\
French bean vr. Kairyo-otebo & 60 & 0 \\
Cabbage vr. Kongo & & \\
\hline
\end{tabular}

a) Number of unwashed bacterial cells adhering to natsudaidai leaf disks was used as a standard. Leaf disks were immersed in the bacterial suspension $\left(1 \times 10^{8}\right.$ cells $\left./ \mathrm{ml}\right)$ for $10 \mathrm{~min}$ and rinsed.

b) Each value represents (number of bacteria adhered to leaf disks pretreated with distilled water containing $25 \mathrm{mM}$ D-glucosamine/that adhered to leaf disks pretreated with distilled water only) $\times 100$

\section{Difference in adhesion of bacterial cells between host and nonhost tissues}

Leaf disks of various plants with a same surface area were exposed to the unwashed 
bacterial cells of $X$. campestris pv. citri, and the relative number of bacterial cells adhering to the disks was determined (Table 3). The unwashed bacterial cells had a general tendency to adhere more specifically to leaf disks of host plants than those of nonhost plants. The adhesion to the disks of host plants were inhibited by D-glucosamine treatment. It was found, however, that the adhesion of these cells was not inhibited in the case of the disk pretreated with D-glucosamine solution.

\section{Discussion}

In the present experiments, it was demonstrated that the number of adhesion of bacterial cells of $X$. campestris pv. citri to citrus leaf disks were far more numerous than that of washed one or unwashed cells of an EPS-nonproducing mutant (Table 2). The adhesion was heavier for wounded leaf tissues than for unwounded ones (Fig. 1). These results indicate that EPS of the bacterial cells may cause the bacterial adhesion by reacting to some substances exposed in the wounded area of host leaf tissues. In relation to these phenomena, it was observed that the disease symptom caused by inoculating the carborundum-rubbed citrus leaf surface with unwashed bacterial cells was heavier and developed faster than that caused by inoculating it with the washed bacterial cells or unwashed ones of a colony mutant having no EPS-producing ability ${ }^{25)}$. It may be, therefore, clear that the interaction between EPS of bacterial cells and some host components is associated with the establishment of host-parasite interaction in citrus canker at least at its initial stage of infection.

Citrus leaves are known to contain a glycoprotein (citrus agglutinin) which causes a visible agglutination in vitro with EPS of $X$. campestris pv. citri at $\mathrm{pH}$ lower than $6.0^{21.23)}$. In the present experiments, the adhesion of bacterial cells through EPS took place in distilled water at $\mathrm{pH}$ of about 6.0. Accordingly, it seemed that the agglutinin activity was not involved in the bacterial adhesion to leaf disks. It was apparent, however, that the bacterial adhesion to citrus leaf tissues through EPS was inhibited by D-glucosamine which is a specific inhibitor of the agglutinin activity (Table 2). In the previous experiments, the agglutinin caused agglutination with EPS only at low $\mathrm{pH}$, not at $\mathrm{pH}$ higher than 6.0, but its interaction with EPS even at $\mathrm{pH} 7.0$ has already been reported, although it was not a visible agglutination ${ }^{24)}$. It assumed, therefore, the agglutinin may be bound to host tissues while exposing a moiety responsible for the interaction with EPS at physiological $\mathrm{pH}$ in tissues. The experiments disclosed that pretreatment of citrus leaf tissues with pronase or low $\mathrm{pH}$ solution, which is known to degenerate the agglutinin or to cause its liberation from wounded tissues, prevented the adhesion of unwashed bacterial cells of $X$. campestris pv. citri. From these findings, it can be inferred that the agglutinin in citrus leaves is involved in the bacterial cell adhesion through EPS.

In the case of nonhost plant tissues, the unwashed bacterial cells were bound to wounded tissues to some extent, and it was found that treatment with D-glucosamine did not inhibit the adhesion of the bacteria (Table 3). The adhesion of washed bacterial cells to citrus leaf tissues were also observed to some extent, but not inhibited 
by D-glucosamine. It is, therefore, that these adhesion may be progressed through a different way from the interaction between EPS of $X$. campestris pv. citri and the citrus agglutinin.

In the mature citrus leaves, the infiltrated mutant cells lacking EPS producing ability failed to grow, and decreased the number of living cells rapidly in the leaf tissues $^{25)}$, However, when these mutant cells were infiltrated into the leaf tissues together with EPS produced by the parental bacteria, they continued to live or grow ${ }^{25)}$. These phenomena suggest that the adhesion of EPS of bacterial cells to the agglutinin in citrus leaf tissues may lead not only to the infectious adhesion but also to the creation of a host environment favourable for the establishment of the initial step of bacterial growth.

We are grateful to Dr. M. Goto, Plant Pathology Laboratory, Shizuoka University, for generous supplying the bacterial cultures, and to Drs. N. Nisimura, C. Matsui and T. Taniguchi, Nagoya University, for valuable discussion.

\section{Literature cited}

1. Bhuvaneswari,T. V., Pueppke, S. G. and Bauer, W. D. (1977). Plant Physiol. $60: 486-491$.

2. Bohlool, B. B. and Schmidt, E. L. (1974). Science $185: 269-271$.

3. Cason, E. T. Jr., Richardson, P. E., Brinkerhoff, L. A. and Gholson, R. K. (1977). Phytopathology $67: 195-198$.

4. Cason, E. T. Jr., Richardson, P. E., Essenberg, M. K., Brinkerhoff, L. A., Johnson, W. M. and Venere, R. J. (1978). Ibid. $68: 1015-1021$.

5. Dazzo, F. B. and Hubbell, D. H. (1975). Appl. Microbiol. $30: 1017-1033$.

6. Dazzo, F. B., Tanke, W. E. and Brill, W. L. (1978). Biochem. Biophys. Acta 539 : 276-286.

7. Goodman, R. N., Huang, P. Y. and White, J. A. (1976). Phytopathology $66: 754-764$.

8. Goto, K., Inoue, Y., Fukatsu, R. and Ohta, K. (1955). Bull. Div. Pl. Breed. Cụlt., Tokaikinki $2: 53-68$.

9. Goto, M. (1962). Bull. Fac. Agr. Shizuoka Univ. L2 : 3-72.

10. Hamblin, J. and Kent, S. P. (1973). Nature, New Biol. $245: 28-30$.

11. Huang, Pi-Yu, Huang, J. S. and Goodman, R. N. (1975). Physiol. Plant Pathol. 6:283-287.

12. Huang, J. S. and Van Dyke, C. G. (1978). Ibid. 13:63-72.

13. Politis, D. J. and Goodman, R. N. (1978). Phytopathology $68: 309-316$.

14. Roebuck, P., Sexton, R. and Mansfield, J. W. (1978). Physiol. Plant pathol. 12:151-157.

15. Sequeira, L., Gaard, G. and De Zoeten, G. A. (1977). Ibid. $10: 43-50$.

16. Sequeira, L. and Graham, T. L. (1977). Ibid. $11: 43-54$.

17. Sequeira, L. (1978). Ann. Rev. Phytopathol. $16: 453-481$.

18. Serizawa, S. and Inoue, K. (1974). Bull. Sizuoka Pref. Citrus Exp. Sta. $11: 54-67$.

19. Sigee, D. C. and Epton, H. A. S. (1975). Physiol. Plant Pathol. 6:29-34.

20. Sing, V. O. and Schroth, M. N. (1977). Science $197: 759-761$.

21. Takahashi, T., Doke, N. and Goto, M. (1981). Ann. Phytopath. Soc. Japan 47, 395 (Abstr. in Japanese)

22. Takahashi, T. and Doke, N. (1982). Ibid. 48:375. (Abstr. in Japanese)

23. Takahashi, T. and Doke, N. (1983). Ibid. 49:600-609.

24. Takahashi, T. and Doke, N. (1984). Physiol. Plant Pathol. (In press).

25. Takahashi, T. and Doke, N. (1984). Proc. of Ann. meeting of Phytopath. Soc. of Japan pp. 103.

26. Wolpert, J. S. and Albersheim, P. (1976). Biochem. Biophys. Res. Commun. 70:729-737.

27. Yoshimura, S. (1963). Bull. Hokuriku Agr. Exp. Sta. $5: 107-127$. 


\title{
和 文 摘 要
}

\author{
カンキツかいよう病菌の感染前過程におけるカンキツ \\ 葉組織への付着と菌体外多糖質の役割
}

\author{
高橋敏房・道家紀志
}

菌体外多糖質 (EPS) を除去していない，カンキツかいよう病菌非洗浄菌体は，カンキツ葉の傷害部に特異 的に付着するが，無傷部にはほとえど付着しなかった。EPS を遠心法で除去した洗浄菌体，および EPS 非 生産変異株菌体は, 傷害部にあほとんど付着しなかった。

非洗浄菌体の葉組織への付着は，D-グルコサミン，プロナ--ゼあるいは pH 4.0 のクエン酸緩衡液で組織 を前処理した場合に，阻害された。非洗浄菌体は，各種の非宿主植物葉の傷害部にも付着したが，この付着に は D-グルコサミンによる阻害はみられなかった。

これらの結果から，カンキツかいよう病菌は，その EPS がカンキツ葉傷寒部に存在する EPS 凝集素と選 択的に付着し, その付着がカンキツかいよう病における宿主一寄生菌関係の成立初期段階に深く関っているて とが推察された。 